\title{
Gastroenterology in Australia, 1949-69
}

\author{
Stanley Goulston \\ F.R.C.P., F.R.A.C.P.
}

Honorary Physician-in-Charge,

\author{
KERRY BREEN \\ M.R.A.C.P.
}

Registrar,

\section{A. W. Morrow Department of Gastroenterology, Royal Prince Alfred Hospital, Sydney}

In 1949 Gastroenterology as a speciality was a Cinderella in Australian medicine. The Clinical Research Unit of the Walter and Eliza Hall Institute, Melbourne, under the direction of Ian Wood, was established as the first research unit and was joined by young men such as Saint, King, Joske, Finckh and Mackay, all to become distinguished in their own right. The A. W. Morrow Unit at the Royal Prince Alfred Hospital, Sydney, was just beginning, and 10 years were to pass before the Gastroenterological Society of Australia was inaugurated in 1959.

In this paper, the authors have endeavoured to present an account of some important contributions by Australians in the last 20 years. Of necessity there are many omissions. Paediatric gastroenterology and studies on the oesophagus have regretfully been left out and few surgical contributions have been mentioned.

\section{Stomach}

\section{Studies on gastritis}

The introduction of a flexible gastric biopsy tube by Wood and his colleagues (1949) provided a new technique which resulted in a clear understanding of the histopathology of gastritis in its various stages and forms. The value of this work was that it placed the hitherto vague clinical entity of gastritis on an objective scientific basis. It also lead directly to the development of the aspiration jejunal biopsy technique. A series of papers from the Clinical Research Unit of the Walter and Eliza Hall Institute, Melbourne, followed. Gastric morphology was found to relate well with gastric secretory activity (Wood et al., 1949). Studies were made of the effects of Xirradiation on the gastric mucosa over a period of time (Joske, Finckh \& Wood, 1955), and this helped to establish the limited indications for this method of treatment of chronic duodenal ulceration. The histology of the unaffected gastric mucosa in gastric ulcer, duodenal ulcer and in gastric carcinoma was studied in depth (Wood \& Taft, 1958). A classical study of the sequential gastric biopsies in 100 cases of pernicious anaemia before and after successful therapy with vitamin $\mathbf{B}_{12}$ showed no improvement in histology (Wood \& Taft, 1958). Attention was drawn to a group of elderly subjects with atrophic gastritis, possible candidates for minor vitamin $\mathbf{B}_{\mathbf{1 2}}$ deficiency but who rarely develop classical pernicious anaemia (Wood et al., 1964). At this time Mackay first reported his autoimmune serological studies in atrophic gastritis.

\section{Biochemical changes in gastric juice}

Piper and his colleagues from the Royal North Shore Hospital, Sydney, extensively studied the biochemical changes in gastric juice in patients with gastric carcinoma in an endeavour to establish the secretory abnormality associated with or causing cancer. They found in gastric carcinoma a fall in acid and pepsin output, a rise in lactic acid concentration and output, and a rise in beta glucuronidase and lactic dehydrogenase content of gastric juice. Other enzymes found to be increased were glutamic oxaloacetic transaminase and phosphohexisomerase (Piper et al., 1963; Piper, 1968).

\section{Treatment of peptic ulceration}

In an endeavour to make a practical contribution to the rational use of antacids and anticholinergics in gastric and duodenal ulceration, Piper evaluated the various marketed cholinergic drugs, assessing their potency, duration of action, selectivity and cost (Piper, 1967).

Myhill and Piper calculated the antacid dosage needed to neutralize gastric secretion in duodenal and gastric ulcer patients and applied this knowledge to the known neutralizing capacity of various antacids in vitro, attempting to rationalize the use of alkalis in peptic ulcer management (Myhill \& Piper, 1964; Piper \& Fenton, 1964). However, Baume \& Hunt (1969) applying these principles in a controlled trial in patients with gastric ulcers found no significant effect on ulcer healing. 


\section{Epidemiology of gastric ulcer}

A notable epidemiological survey of the incidence of gastric ulcer was made single-handed by a clinical gastroenterologist. Billington from the Prince Henry Hospital, Sydney. In a survey of the gastric ulcer patients admitted to four Sydney teaching hospitals he found that since 1945 a sudden exacerbation of chronic gastric ulceration had occurred in young women (Billington, 1960). Next, he surprisingly showed the rising incidence was limited to N.S.W. and Queensland and was not present in Victoria (Billington, 1963). He later found that a pattern was emerging that more women of all ages were developing gastric ulcers (Billington, 1965). The pathogenesis of this phenomenon remained obscure.

Gillies and Skyring from the Royal Prince Alfred Hospital in an inpatient study revealed an associa. tion between gastric ulcer and aspirin ingestion. smoking and a family history of ulcer. There was also an association between duodenal ulceratior: and family history (Gillies \& Skyring, 1968). In a further study involving a large-scale investigatiol. into employees of three separate organizations, these inpatient findings were confirmed (Gillies \& Skyring, 1969). The association between aspirin ingestion and gastric ulcers was striking and suggested a causal relationship. Chapman \& Duggan (1969) also implicate aspirin mixtures and gastric ulcer.

\section{Aspirin and gastrointestinal bleeding}

Studies at Royal Prince Alfred Hospital, Sydney, demonstrated that the faecal blood loss caused by ingestion of unbuffered aspirin was increased by alcohol, although alcohol alone did not cause gastrointestinal bleeding (Goulston \& Cooke, 1968). The same group also showed that intravenous aspirin did not increase gastrointestinal blood loss (Cooke \& Goulston, 1969), and that paracetamol did not cause bleeding from the stomach (Goulston \& Skyring, 1964).

Recently, St John and McDermott from the Alfred Hospital, Melbourne, have shown that aspirin may cause bleeding in patients with pernicious anaemia thus demonstrating the importance of factors other than the pH of gastric content in the mechanism of aspirin bleeding (St John \& McDermott, 1969).

\section{Postgastrectomy phenomena}

While working in the Nuffield Department of Clinical Medicine, Oxford, with Professor L. J. Witts, Dellar played a major role in a series of investigations concerned with postgastrectomy phenomena. The first was a demonstration that the absorption of radioactive vitamin $\mathbf{B}_{12}$ after partial gastrectomy may be significantly enhanced when the test dose is given with a vitamin $\mathbf{B}_{12}$-free meal (Deller,
Germar \& Witts, 1961). Deller \& Witts (1962) showed that after partial gastrectomy vitamin $\mathbf{B}_{\mathbf{1 2}}$ deficiency is not as rare as had been previously thought. A progressive fall in the level of vitamin $\mathbf{B}_{12}$ in serum occurred after operation particularly in the first 6 years. They further showed that this fall was mainly due to loss of intrinsic factor (Deller, Richards \& Witts, 1962). A report of twenty-seven cases of megaloblastic anaemia following partial gastrectomy provided evidence linking this anaemia with vitamin $B_{12}$ deficiency (Deller, 1962).

Returning to the Department of Medicine, University of Adelaide, Deller continued studies into the metabolic effect of gastrectomy in man. The incidence of skeletal rarifaction was investigated and found to be twice as frequent and more severe in a gastrectomy group as the control group. The interval of time after gastrectomy and advancing age were accelerating factors (Deller \& Begley, 1963). The nature of the skeletal abnormality was described as 'osteomalacic' representing a combination of osteomalacia and osteoporosis (Deller, Edwards \& Addison, 1963; Deller et al., 1964). Measuring calcium absorption by whole body gamma-spectrometry, he also demonstrated frequent impaired absorption of calcium 47 in postgastrectomy patients (Deller, 1966).

\section{Environmental factors in gastric morphology and gastric secretory activity}

A study on the behaviour of gastric epithelium in dogs under various experimental circumstances was conducted in the Departments of Surgery and Pathology in the University of Sydney (Milton, Maxwell \& Finckh, 1960; Milton, 1962). Removal of the entire gastric mucosa of dogs leaving only a few scattered differentiated epithelial cells was followed by the entire reconstitution of the mucous membrane in three months, including gastric tubules with parietal and chief cells. Further work demonstrated the importance of environment on the behaviour and functioning of the gastric epithelium (Milton \& Finckh, 1960), and showed that an intact muscularis mucosae was vital for full differentiation of healing epithelium after damage (Finckh \& Milton, 1960).

\section{Gastric physiology}

Cooke, from Sydney, working in Dr Morton Grossman's Department in Los Angeles, made some important contributions to the understanding of the physiology of the stomach and pancreas. Proof that gastrin stimulates pancreatic secretion was demonstrated for the first time (Preshaw, Cooke \& Grossman, 1965). The initial evidence was provided that gastrin released endogenously could stimulate acid secretion equal to that of maximal histamine or 
maximal exogenous gastrin, that acetylcholine does not have an all or none effect on releasing gastrin, and that gastrin stimulates gastric pepsin secretion (Cooke et al., 1967). The relative potencies of various releasers of gastrin from the pyloric antrum were compared, and it was demonstrated that acetyl choline was the most important stimulant (Cooke \& Grossman, 1968). The evidence that potentiation of acid secretion does exist in dogs with intact stomachs established an important principle (Cooke, 1969).

\section{The small intestine}

There have been many contributions in this field, both at a physiological and a clinical level. The demonstration that malabsorption could follow acute temporary occlusion of the superior mesenteric artery in man (Joske, Shamm'a \& Drummery, 1958), led to subsequent reports of temporary malabsorption secondary to acute enteritis (King \& Joske, 1960 ), primary jejunal carcinoma possibly secondary to adult coeliac disease (Joske, 1960) and the peroral biopsy appearances of gastric and jejunal mucosa in malabsorption following partial gastrectomy (Joske \& Blackwell, 1959).

The Clinical Research Unit at the Royal Melbourne Hospital maintained a continuing interest in small bowel disease via the application of their gastric suction biopsy instrument to the small bowel (Ralston, Wood \& Hughes, 1960). They demonstrated that gross gastric mucosal changes in a variety of conditions were not reflected in the jejunal biopsy appearances.

In paediatric gastroenterology, the Gastroenterology Research Unit at the Royal Children's Hospital in Melbourne directed by Charlotte Anderson, has has made many important contributions. Unfortunately, lack of space precludes a just acknowledgement of this group's work. In the field of malabsorption, they were the first in the English literature to report isolated monosaccharide malabsorption (Anderson, Kerry \& Townley, 1965). The long-term follow-up of patients with mucoviscidosis (Gracey \& Anderson, 1969 ) is another example of their range of experience.

Lactase deficiency and lactose intolerance have aroused much interest in recent years. Limited Australian and South East Asian populations have been the subject of study, best exemplified by the work of Bolin, Crane \& Davis (1968) from the Prince Henry Hospital, Sydney, who reported a very high incidence of lactose intolerance in Chinese and Indian students resident in Australia and in New Guinea natives. A second report indicated a similar incidence amongst Asians in their own countries (Davis \& Bolin, 1967). It was suggested that an adaptive decline in intestinal lactase activity followed withdrawal of milk from the diet after weaning, but evidence that such a process does take place is lack- ing. A high incidence of lactose intolerance has also been found in aboriginal children (Elliot, Maxwell \& Vawser, 1967).

Malabsorption of therapeutic oral iron supplements due to binding by magnesium trisilicate antacids has recently been demonstrated by Hall \& Davis (1969).

Other contributions in the field of malabsorption include studies on the association between small bowel morphology and malignant disease. In a study of forty-five patients with malignant disease, normal morphology was found in only $38 \%$ (Deller, Murrell \& Blowes, 1967). The degree of villous atrophy found correlated best with the duration of the patient's illness and his degree of weight loss.

Fone has had a continuing interest in adult coeliac disease dating from his observations with Cooke in Birmingham on the interpretation of jejunal biopsy appearances (Fone et al., 1960). He has reported a representative picture of adult coeliac disease in Australia from his experience at the Royal Melbourne Hospital (Fone, 1968). A further contribution has been a detailed retrospective study of forty-one cases of Crohn's disease (Fone, 1966).

Deller and Wangel have published detailed studies of intestinal motility using a combination of openended catheter pressure recordings and cineradiography in normal man, in patients after partial gastrectomy and in those with large bowel dysfunction (Deller \& Wangel, 1965; Wangel \& Deller, 1965a, b).

Another Adelaide worker, Murrell, has made observations on an unusual illness occurring in the highlands of New Guinea (Murrell, 1967). These people suffer a severe necrotizing enteritis, given the local name of 'pig-bel', which is probably caused by Clostridium welchii type $\mathrm{C}$ from eating pork.

The A. W. Morrow Unit at the Royal Prince Alfred Hospital in Sydney has been the source of some uncommon clinical reports including cases of ulcerative jejunitis with malabsorption (Goulston, Skyring \& McGovern, 1965) and a patient with intestinal lymphangiectasia who appeared to respond to the surgical procedure of lympho-venous anastomosis (Mistilis, Skyring \& Stephen, 1965). Gallagher has pursued studies of vitamin $\mathbf{B}_{12}$ absorption in suckling rats (Gallagher, 1969). His work suggests that pinocytosis is the mechanism of absorption. Weaning coincides with the disappearance of pinocytosis and the onset of adrenocortical function. It would seen that cortisone influences the morphological development of the rat intestinal epithelium.

Other papers from this department concern studies on the use of isotopic methods in the diagnosis of protein-losing enteropathy (Walker-Smith, Skyring \& Mistilis, 1966), the investigation of steatorrhoea 
(Goulston, Bhanthumnavin \& Harrison, 1968) and the incidence of small bowel tumours (Middleton, 1967).

\section{The colon}

\section{Ulcerative colitis}

Rankin et al. (1960) (A. W. Morrow Unit, Sydney) as a result of their experience of fulminant cases strongly advocated a planned agressive approach to this serious phase of the disease which was vindicated in a later report (Gallagher et al., 1962). Mortality was reduced by $61 \%$ to $9 \%$. Early diagnosis, vigorous supportive therapy, early and repeated team assessment and ileostomy and subtotal colectomy performed early if no improvement occurred were points emphasized. This regime has been generally adopted now in most countries.

A result of the Unit's experience in ulcerative colitis has been the reporting of the nature of the body's response to total colectomy and ileostomy (Gallagher, Harrison \& Skyring, 1962) and a study of the effect of mineralocorticoids on small intestinal fluid and electrolyte balance (Goulston, Harrison \& Skyring, 1963). They demonstrated that the kidneys could conserve fluid and electrolyte in these patients, that mineralocorticoids affect the small bowel in a manner identical to the effect on renal function, and emphasized the life-threatening risk of excessive sodium loss in the ileostomy subject.

McGovern \& Archer (1957) had previously provided an explanation for the extension of ulcers in fulminant colitis from the superficial mucosa into the depths of the submucosa and even into muscle. These workers found an excess of mast cells in the bowel wall in ulcerative colitis sufficient to give rise to histamine release. Liberated histamine may cause the vascular congestion and the spastic state of the colonic musculature. This led Goulston \& McGovern (1969) to study patients with benign strictures in ulcerative colitis. Measurements of the thicknesses of the various components of the bowel wall showed that such strictures were due to a remarkable increase in thickness and hypertrophy of the muscularis mucosae.

An epidemiological study of childhood ulcerative colitis in N.S.W. was conducted by Skyring \& Roberts (1965) from the same department. Virtually all children in N.S.W. were covered in the survey between 1950 and 1962 . The survival rate was calculated by the actuarial method, and after 12 years was $76 \%$ and the percentage requiring surgery after this time was $46 \%$. A large percentage $(12 \%)$ were asthmatic. The major precipitating and exacerbating factors of colitis were emotional upsets and infection.

Hughes, from the Royal Melbourne Hospital, has written extensively on many aspects of colonic disease and in particular on the surgery of ulcerative colitis. He found carcinoma supervening on ulcerative colitis in $4 \%$ of all his cases and in $25 \%$ of those with colitis present for ten or more years (Russell \& Hughes, 1961). Mild cases of ulcerative colitis involving only the rectum did well with little active treatment (Hughes, 1961a). He advocated a one-stage ileostomy and subtotal colectomy for fulminant ulcerative colitis and found that primary proctocolectomy was not warranted because of the high operative mortality rate (Hughes, 1961b). A review of a large personal series of 908 patients including sixty-five children with ulcerative colitis was made (Hughes, 1969). If the rectum was of doubtful quality, colectomy and ileostomy were performed initially. If the rectum was smooth and had a good capacity a one-stage ileorectal anastomosis was preferred. A one-stage procto-colectomy was not recommended in children. In recent years Hughes has performed more ileorectal anastomoses for ulcerative colitis and described his results in the first forty-eight cases in 1967 (Hughes, 1967). In most cases the rectum remained involved, the patient required constipating drugs and most failures occurred in the first year after operation.

\section{Crohn's disease}

McGovern \& Goulston (1968) from the Royal Prince Alfred Hospital, described their experience of Crohn's disease of the colon. The patients were divided into those with total involvement (ileal colitis) and those with colitis alone. Surprisingly, the former group fared better. The earliest pathological lesion was described, emphasis being placed on the basal cells of the mucosal tubules in the mucosa being destroyed by an accumulation of lymphocytes.

\section{Ischaemic enterocolitis}

A retrospective study led to the independent recognition of an entity, ischaemic enterocolitis, occurring in patients with underlying severe cardiac, renal or respiratory disease, and precipitated by episodes of hypotension (McGovern \& Goulston, 1965). The mesenteric arteries were patent. The pathology was found to be a specific one. This entity can be distinguished from ischaemic colitis due to occlusion of a major mesenteric artery (Goulston \& McGovern, 1968). The frequency and importance of these two conditions are now accepted and form part of the differential diagnosis of colitis especially in the middle or older age group.

\section{Pseudo-membranous colitis}

The concept of pseudo-membranous colitis only being a post-operative phenomenon and related to staphylococcal infection after antibiotic therapy was 
disputed by Goulston \& McGovern (1965). They showed that this condition could accompany other causes of colitis, could follow a debilitating illness, or occur as a result of colonic obstruction generally by carcinoma.

\section{The liver}

\section{Active chronic hepatitis}

The Clinical Research Unit of the Walter \& Eliza Hall Institute in Melbourne has retained an interest in the problems of chronic hepatitis since 1948. One of the first detailed studies of a large series of patients with hepatitis (Saint et al., 1953) emphasized the significance of hypergammaglobulinaemia, and noted the poor prognosis of the active chronic group. Joske \& King (1955) described two patients with active chronic hepatitis with the lupus cell phenomenon and suggested that this resulted from a primary disorder of the antibody-producing mechanism. Over subsequent years, this Unit has provided evidence in support of the concept that active chronic hepatitis is an autoimmune form of hepatitis. Mackay \& Gajdusek (1958) described an autoimmune complement fixation reaction in human serum hepatitis and considered that this abnormal serum reactivity may characterize the transition of acute hepatitis to the chronic stage.

Mackay coined the term 'lupoid hepatitis' indicating active chronic hepatitis with the L.E. cell phenomenon and described his five markers for an autoimmune reaction, namely, hypergammaglobulinaemia, circulating autoantibodies, lymphoid infiltration, response to cortisone and concurrence with other autoimmune lesions (Mackay, 1961). He emphasized that autoimmunity may be of chief importance as a cause of persistent destructive hepatitis. More recently, Goldstein \& Mackay (1967) in a computer analysis in lupoid hepatitis of those indices considered to be part of the hepatocellular damage phase and those indicative of an immune response, felt that sufficient interrelationships existed to suggest that they would be mutually interdependent. The demonstration of the smooth muscle antibody in 'autoimmune hepatitis' was reported in two papers by Whittingham et al. (1966), and has proved of value in distinguishing between lupoid hepatitis and disseminated lupus erythematosis.

The controversy as to whether active chronic hepatitis and lupoid hepatitis represent primary autoimmune disease, or whether the immune reaction is secondary still goes on. A valuable model for the study of the experimental demonstration of virus induction of autoimmune disease in mice was reported by Joske et al. (1966).

Articles dealing with the clinical aspects of chronic hepatitis by Mackay \& Wood $(1961,1962,1963)$ and developing their autoimmune hypothesis, have been matched by the comprehensive account of this disorder by Mistilis, Skyring \& Blackburn (1968) from the A.W. Morrow Department and Department of Medicine, University of Sydney. A cumulative survival study for treated and untreated patients demonstrated increased survival in the $2 \mathrm{nd}$, 3rd and 4th years of the treated group while after the 6th year, the two groups approximated. Mistilis (1968) reported the pathology of active chronic hepatitis in detail, emphasizing the value of aspiration liver biopsy as being essential for the diagnosis and a guide to prognosis.

In an early study of the effect of corticosteroids in active chronic hepatitis O'Brien, Goble \& Mackay (1958) considered that cortisone reduced the rate of liver cell necrosis in relapses, and used the serum transaminase levels as an index of liver cell necrosis.

Later experience confirmed that the management of chronic hepatitis with corticosteroid therapy and short term use of immunosuppressives (Mackay \& Wood, 1963; Mackay, Weiden \& Ungar, 1964) gave favourable results. Arter, Perkins \& Blackburn (1966) also reported satisfactory results using 6mercaptopurine or azothioprine, but stressed there was no associated histopathological benefit. A larger series of patients treated with these agents was subsequently reported (Mistilis et al., 1968) and the above findings were confirmed.

\section{The sequelae of infectious hepatitis}

King (1946) gave an early account of the possible sequelae of infectious hepatitis in Melbourne. Gallagher \& Goulston (1962) emphasized the occasional persistence of the clinical and pathological signs of acute viral hepatitis for as long as three years. McGuinness \& Joasoo (1969) reported the association of aplastic anaemia and infectious hepatitis.

\section{The liver in ulcerative colitis}

Liver disease in chronic ulcerative colitis was an early interest in the A. W. Morrow Department. Boden et al. (1959) were alerted by the finding of high serum alkaline phosphatase readings in ulcerative colitis patients, and demonstrated the occurrence of a pericholangitis involving all structures of the portal tracts. The hypothesis of an intermittent or continuous portal bacteraemia as the cause led to the use of tetracycline in the treatment (Rankin et al., 1959). In a later review of the subject Mistilis \& Goulston (1965) showed that pericholangitis was the commonest type of liver damage in ulcerative colitis, and the clinical and biochemical findings and the course and outcome of the disorder were traced by sequential liver biopsies. Treatment by antibiotics, corticosteroid therapy or surgery did 
not appear to influence the course of the liver disease once it was well established (Mistilis, Skyring \& Goulston, 1965a). Mistilis also reviewed the pathology (1965) in detail and Mistilis et al. (1965b) the effect of long-term therapy. Rankin, Skyring \& Goulston (1966) reported the high incidence of bile duct carcinoma in patients with chronic ulcerative colitis.

Thorpe, working with Professor Sheila Sherlock in London described the occurrence of sclerosing cholangitis in chronic ulcerative colitis (Thorpe, 1967).

\section{Portal hypertension}

Blackburn (1956) from the Department of Medicine, University of Sydney, reported functionally significant acquired anastomoses between the left pulmonary vein and the portal venous system in a patient with extrahepatic portal hypertension, following splenectomy and oesophagogastrectomy for bleeding oesophageal varices. The frequency of arterial oxygen desaturation in patients with chronic liver disease was studied and a proportion of these were found to have an abnormal degree of venoarterial shunting (mainly intrapulmonary) ranging up to $20 \%$ or more of the cardiac output (Blackburn et al., 1960).

Stathers, Ma \& Blackburn (1968) described a clinical evaluation of a large group of patients with extrahepatic portal hypertension. The commonest causes of bleeding were salicylates, pregnancy and bone fragments. Conservative management was usually satisfactory. Portal systemic encephalopathy treated with benefit with lactulose was reported by Ma, McLeod \& Blackburn (1969).

\section{Hepatic electron microscopy}

With colleagues at the Royal Free Hospital, London, Thorpe developed a method for the demonstration of copper under the electronmicroscope (Scheuer, Thorpe \& Marriott, 1967). Tissue samples for copper determination were handled by neutron activation analysis (Todd, Thorpe \& Rosenoer, 1967). Later in the Department of Medicine, University of N.S.W., Thorpe \& Shorey (1966a) studied the ultrastructural alterations in human fatty livers. Alterations to the endoplasmic reticulum was found to be the main lesion. The longterm administration of alcohol to adult male rats produced dilatation of the membrane of the granular endoplasmic reticulum (Thorpe \& Shorey, 1966b).

In an electron microscopy study of a needle aspiration liver biopsy specimen of a patient demonstrated at laparotomy to have a primary hepatoma, Ma \& Blackburn (1966) found virus-like particles, the first such report to be described.

\section{Liver disease in Papua and New Guinea}

An important field study from the University of
Sydney studying liver disease in the Highland population of the Territory of Papua and New Guinea, was reported in two papers (Arter et al., 1968 and Ma et al., 1968). They found a very high incidence of liver disease-over $70 \%$-the most frequent lesion being a form of pericholangitis found in $70 \%-90 \%$ of all biopsies. The disease ran a generally benign course without significant effect on hepatic function. No progression to cirrhosis or malignancy was demonstrated.

\section{Anaemia in chronic liver disease}

Deller and co-workers studied the factors producing anaemia in liver disease. Macrocytic anaemia with megaloblastic bone marrow was most frequently due to folic acid deficiency (Kimber et al., 1965a; Deller, Kimber \& Ibbotson, 1965). As well as macrocytosis, iron deficiency due to alimentary tract blood loss, absolute or relative bone marrow hypofunction and shortening of the red cell life-span was observed (Kimber, Deller \& Lander, 1965b).

\section{Iron and the liver}

Powell and his colleagues from the Department of Medicine, University of Queensland, described a family in which haemochromatosis was present in four women, two still menstruating (Lloyd, Powell \& Thomas, 1964). In an investigation to study iron storage in families with haemochromatosis and those with alcoholic cirrhosis and haemosiderosis, the incidence of increased iron storage in relatives of patients with haemochromatosis was clearly demonstrated both in males and females, supporting the concept that haemochromatosis and alcoholic cirrhosis with haemosiderosis are different entities (Powell, 1965). Tackling the problem of iron storage from another angle, Powell estimated hepatic iron stores in 100 subjects without liver disease at autopsy. There was a significant difference in iron concentration and total iron content between those with heavy and light alcoholic consumption. The finding of stainable iron in the livers of relatives of patients with idiopathic haemochromatosis cannot therefore be interpreted as evidence of a genetic abnormality Powell, 1966). Perkins et al. (1965) from the Clinical Research Unit at Royal Prince Alfred Hospital, describing idiopathic haemochromatosis in a 13-year-old boy emphasized the myocardial and endocrine presentations in childhood.

\section{Copper metabolism in the rat}

Extending the observations previously made on the poor reabsorption of biliary excreted copper, Farrer \& Mistilis (1967) and Mistilis \& Farrer (1968) from the A. W. Morrow Unit and the Department of Medicine, University of Sydney, made a study of the 
ability of adult rats to absorb and excrete radio-copper when administered in different dose ranges and in varying molecular forms. Further studies showed that bile was the major factor in the maintenance of copper homeostasis in the adult rat (Farrer \& Mistilis, 1968).

In an attempt to explain transiently high positive copper balance known to occur during the early neonatal life of the rat, Mistilis \& Mearrick (1969) demonstrated that excessive absorption, and retention via a low level of biliary excretion, would account for this. Cortisone markedly increased faecal elimination of the metal.

\section{The pancreas}

\section{Pancreatitis}

There would appear to be no studies of the incidence of pancreatitis in an unselected Australian population. However, all forms of pancreatitis are seen relatively frequently in Australian hospitals (Saint, 1954; Joske, 1955b, Skyring, Singer \& Tornya, 1965; Davis, 1966) and Australian investigators have made contributions to the delineation of the associated aetiological factors in the pancreatitis syndrome and to the experimental search for the mechanism of pancreatic damage.

Joske has studied many of the clinical aspects of acute pancreatitis, including pancreatitis following pregnancy (Joske, 1955a), the aetiological factors of pancreatitis (Joske, 1955b) and the association of viral hepatitis and pancreatitis (Joske, 1955c) and has recently reviewed his experience in the laboratory diagnosis of pancreatic disease (Joske, 1969).

Over approximately the same period Saint made careful clinical studies of two groups of patients with acute pancreatitis (Saint \& Weiden, 1953; Saint, 1954). The importance of his and Joske's contributions lay in their recognition of the multiple aetiologies of this disease. This paved the way to a more logical approach to the management of recurrent pancreatitis.

A further clinical contribution was the study by Goulston and Gallagher (1962) of painless chronic pancreatitis.

The precise nature of the initiating factor in any episode of pancreatitis remains unknown. At the Baker Institute of Medical Research, in the Alfred Hospital, Melbourne, McCutcheon has studied this aspect in both humans and animals over a 10-year period (McCutcheon, 1968). In 1962, McCutcheon and Race demonstrated that reflux of duodenal contents into the pancreatic duct appeared to be the cause of post-operative pancreatitis in dogs and showed for the first time with barium studies that such reflux could occur in man in vivo. They suggest that the common mechanism of pancreatic damage in the cases clinically associated with cholelithiasis, alcoholism, surgery and other factors is reflux of duodenal contents.

Davis and co-workers demonstrated that acute duodenitis does not occur in their alcoholic patients (Pirola \& Davis, 1968) and that intravenous alcohol would appear to increase the tone of the sphincter of Oddi as measured via $\mathrm{T}$-tubes inserted at elective exploration of the common bile duct. They also showed (Davis \& Pirola, 1966) that intravenous alcohol in normal volunteers reduced the volume of duodenal aspirate with maintenance or elevation of amylase and bicarbonate levels in the aspirate. The application of these studies to the aetiology of alcohol-associated pancreatitis remains theoretical.

\section{Iron metabolism}

The world literature concerning control of normal iron metabolism and factors leading to increased iron absorption in haemochromatosis and haemosiderosis is immense. Although it had been known from animal experiments that pancreatectomy and severe pancreatic damage was associated with increased iron absorption and deposition, it was Davis working with Badenoch (Davis \& Badenoch, 1962) who demonstrated that this occurs in patients with chronic calcific pancreatitis. Deller confirmed this (Deller, 1965). Subsequently, Davis \& Biggs (1964) demonstrated that potent pancreatic extracts appeared to inhibit inorganic iron absorption in haemochromatosis, and that an aqueous solution of pancreatic extract could inhibit iron uptake in isolated intact jejunal loops in the rat (Davis \& Biggs, 1965). They concluded that human duodenal contents seemed to contain a factor capable of inhibiting iron absorption (Davis \& Biggs, 1967).

Deller and co-workers have also studied the control of iron absorption. They reported a specific iron-binding protein present in the gastric juice of normal subjects which limited iron absorption and which they called 'gastroferrin' (Davis, Luke \& Deller, 1966). This substance was not present in patients with haemochromatosis, leading to their theory that lack of 'gastroferrin' might be the basic defect allowing increased iron absorption in haemochromatosis. Studies of the exact nature of this substance are continuing (Rudzki \& Deller, 1969).

This rather sketchy outline of Australian contributions to Gastroenterology during the period 1949-69 forms a basis for a greater volume of original contributions which will appear in the next 20 years. In a sense the contributors, like Cook, have been charting a coastline on the eastern, southern and western seaboards of Australia and laying the foundations for more valuable and exciting discoveries in the future. 


\section{References}

Anderson, C.M., KerRy, K.R. \& ToWnley, R.R.W. (1965) An inborn defect of intestinal absorption of certain monosaccharides. Archives of Disease in Childhood, 40, 1.

Arter, W.J., Perkins, K.W. \& Blackburn, C.R.B. (1966) Experience with the use of 6 Mercaptopurine and Imuran in the treatment of progressive hepatitis (active chronic heptatis). Australasian Annals of Medicine, 15, 222.

Arter, W.J., Stathers, G.M., Ma, M.H., Blackburn, C.R.B. \& McGoverN, V.J. (1968) Liver disease in the highland populations of the Territory of Papua and New Guinea. 1. Observations on liver biopsies from persons selected in field surveys. Tropical and Geographical Medicine, 20, 202.

BAUME, P.E. \& HUNT, J.H. (1969) Failure of potent antacid therapy to hasten healing in chronic gastric ulcers. Australasian Annals of Medicine, 18, 113.

Billington, B.P. (1960) Gastric ulcer: Age, sex and a curious retrogression. Australasian Annals of Medicine, 9, 111.

Billington, B.P. (1963) The Australian gastric ulcer change: Interstate variationj. Australasian Annals of Medicine, 12, 153.

Billington, B.P. (1965) Observations from N.S.W. on the changing incidence of gastric ulcer in Australia. Gut, 6, 121.

BlaCKBURN, C.R.B. (1956) Acquired portal-pulmonary, venous anastomosis complicating partial oesophagogastrectomy in a patient with portal hypertension. Thorax, $2,30$.

Blackburn, C.R.B., Read, J., McRae, J., Colebatch, H.J., Playoust, M.R. \& Holland, R.A.B. (1960) Veno-arterial shunting of blood in chronic liver disease. Australasian Annals of Medicine, 9, 204.

Boden, R.W., Rankin, J., Goulston, S.J.M. \& Morrow, A.W. (1959) The liver in ulcerative colitis. The significance of raised serum alkaline phosphatase levels. Lancet, ii, 245.

Bolin, T.D., Crane, G.G. \& Davis, A.E. (1968) Lactose intolerance in various ethnic groups in South East Asia. Australasian Annals of Medicine, 17, 300.

Chapman, B.L. \& Duggan, J.M. (1969) Aspirin and uncomplicated peptic ulcer. Gut, 10, 443.

CoOKe, A.R. (1969) Potentiation of acid secretion in dogs. American Journal of Physiology, 216, 968.

Cooke, A.R. \& Goulston, K. (1969) Failure of intravenous aspirin to increase gastrointestinal blood loss. British Medical Journal, 3, 330.

Cooke, A.R. \& Grossman, M.I. (1968) Comparison of stimulants of antral release of gastrin. American Journal of Physiology, 215, 314.

Cooke, A.R., NaHRwold, D.L., Preshaw, R.M. \& Grossman, M.I. (1967) Comparison of endogenous and exogenous gastrin in stimulation of acid and pepsin secretion. American Journal of Physiology, 213, 432.

DAvis, A.E. (1966) On the value of pancreatic function studies in the diagnosis of chronic pancreatitis. Medical Journal of Australia, ii, 1144.

DAvis, A.E. \& BADENOCH, J. (1962) Iron absorption in pancreatic disease. Lancet, ii, 6.

DAVIS, A.E. \& BIGGS, J.C. (1964) Iron absorption in haemochromatosis and cirrhosis of the liver. Australasian Annals of Medicine, 13, 201.

Davis, A.E. \& Biggs, J.C. (1965) The pancreas and iron absorption. Gut, 6, 140.

Davis, A.E. \& Biggs, J.C. (1967) The pancreas and iron absorption: Current views. American Journal of Digestive Diseases, 12, 293.

Davis, A.E. \& Bolin, T.D. (1967) Lactose intolerance in Asians. Nature (London), 216, 1244.

Davis, P.S., Luke, C.G. \& Deller, D.J. (1966) Reduction of gastric iron-binding protein in haemochromatosis. A previously unrecognised metabolic effect. Lancet, ii, 1431.

DaVIS, A.E. \& Pirola, R.C. (1966) The effects of ethyl alcohol on pancreatic exocrine function. Medical Journal of Australia, ii, 757.

Deller, D.J. (1962) Megaloblastic and transitional megaloblastic anaemia following partial gastrectomy. Study of 27 cases. Australasian Annals of Medicine, 11, 235.

DeLLER, D.J. (1965) Iron ${ }^{59}$ absorption measurements by whole body counting. Studies in alcoholic cirrhosis, haemochromatosis and pancreatitis. American Journal of Digestive Diseases, 10, 249.

DelleR, D.J. (1966) Radiocalcium absorption after partial gastrectomy. American Journal of Digestive Disorders, 11, 10.

Deller, D.J. \& Begley, M.D. (1963) Calcium metabolism and the bones after partial gastrectomy. 1. Clinical features and radiology of the bones. Australasian Annals of Medicine, 12, 282.

Deller, D.J., Begley, M.D., Edwards, R.G. \& Addision, M. (1964) Metabolic effects of partial gastrectomy with special reference to calcium and folic acid. Part 1: Changes in calcium metabolism and the bones. Gut, 5, 218.

Deller, D.J., EdWards, R.G. \& Addison, M. (1963) Calcium metabolism and the bones after partial gastrectomy. 2. The nature and cause of the bone disorder. Australasian Annals of Medicine, 12, 295.

Deller, D.J., Germar, H. \& WitTs, L.J. (1961) The effect of food on absorption of radioactive Vitamin $B_{12}$. Lancet, i, 574.

Deller, D.J., Kimber, C.L. \& Ibbotson, R.N. (1965) Folic acid deficiency in cirrhosis of the liver. American Journal of Digestive Diseases, 10, 35.

Deller, D.J., Murrell, T.G.C. \& Blowes, R. (1967) Jejunal biopsy in malignant disease. Australasian Annals of Medicine, 16, 236.

Deller, D.J., RichaRds, W.C.D. \& WitTs, L.J. (1962) Changes in the blood after partial gastrectomy with special reference to Vitamin $B_{12}$. 2. The cause of the fall in serum Vitamin B 1 . Quarterly Journal of Medicine, 31, 89.

DeLLER, D.J. \& WANGEL, A.G. (1965) Intestinal motility in man. 1. A study combining the use of intraluminal pressure recording and cineradiography. Gastroenterology, 48, 45.

Deller, D.J. \& WiTTS, L.J. (1962) Changes in the blood after partial gastrectomy with special reference to Vitamin $B_{12}$ : Serum vitamin $B_{12}$, haemoglobin, serum iron, and bone marrow. Quarterly Journal of Medicine, 31, 71.

Elliot, R.B., MaXWell, G.M. \& Vawser, N. (1967) Lactose maldigestion in Australian aboriginal children. Medical Journal of Australia, i, 46.

FARRER, P.A. \& Mistilis, S.P. (1967) Absorption of exogenous and endogenous biliary copper in the rat. Nature (London), 213, 291.

FARRER, P.A. \& Mistilis, S.P. (1968) Copper metabolism in the rat: Studies of the biliary excretion and intestinal absorption of ${ }^{64} \mathrm{Cu}$-labelled copper. Wilsons Disease (Ed. by D. Bergsma). Birth Defects: Original Article Series, No. 4, 14.

Finckh, E.S. \& Milton, G.W. (1960) Regeneration of gastric mucosa from differentiated cells. Journal of Pathology and Bacteriology, 80, 143.

FONE, D.J. (1966) Regional enteritis (Crohn's disease). Medical Journal of Australia, i, 865.

Fone, D.J. (1968) Malabsorption in Australia. Proceedings of the Third Asian-Pacific Congress in Gastroenterology, 3, 122.

Fone, D.J., CoOKe, W.T., MeYnell, M.M., HaRris, E.L. \& Cox, E.B. (1960) Jejunal biopsy in adult coeliac disease and allied disorders. Lancet, i, 933.

Gallagher, N.D. (1969) Mechanism and site of Vitamin B B $^{12}$ absorption in suckling rats. Nature (London), 222, 877. 
Gallagher, N.D. \& Goulston, S.J.M. (1962) Persistent acute viral hepatitis. British Medical Journal, 1, 906.

Gallagher, N.D., Goulston, S.J.M., Wyndham, N. \& Morrow, A.W. (1962) The management of fulminant ulcerative colitis. Gut, 3, 306.

Gallagher, N.D., Harrison, D.D. \& Skyring, A.P. (1962) Fluid and electrolyt disturbances in patients with long established ileostomies. Gut, 3, 219.

Gillies, M.A. \& Skyring, A.P. (1968) Gastric ulcer, duodenal ulcer and gastric carcinoma: A case-control study of certain social and environmental factors. Medical Journal of Australia, ii, 1132.

Gillies, M.A. \& Skyring, A.P. (1969) Gastric and duodenal ulcer: The association between aspirin ingestion, smoking and family history of ulcer. Medical Journal of Australia, ii, 280.

Goldstein, G. \& Mackay, I.R. (1967) Lupoid hepatitis: Computer analysis defining 'hepatitis' and 'cirrhosis': Phases and relationships between hepatocellular damage and immune reaction in the liver. Australasian Annals of Medicine, 16, 62.

Goulston, K., Bhanthumnavin, K. \& Harrison, D.D. (1968) Investigation of steatorrhoea. Medical Journal of Australia, ii, 462.

Goulston, K. \& Cooke, A.R. (1968) Alcohol, aspirin and gastrointestinal bleeding. British Medical Journal, 4, 664.

Goulston, S.J.M. \& Gallagher, N.D. (1962) Chronic painless pancreatitis. Gut, 3, 252.

Goulston, K., Harrison, D.D. \& Skyring, A.P. (1963) Effect of mineralocorticoids on the sodium/potassium ratio of human ileostomy fluid. Lancet, ii, 541 .

Goulston, S.J.M. \& McGoverN, V.J. (1965) Pseudomembranous colitis. Gut, 6, 207.

Goulston, S.J.M. \& McGovern, V.J. (1968) The recognition of ischaemic enterocolitis as an important entity. (Abstract). Australasian Annals of Medicine, 17, 163.

Goulston, S.J.M. \& McGoverN, V.J. (1969) The nature of benign strictures in ulcerative colitis. New England Journal of Medicine, 281, 290.

Goulston, K. \& SKYrING, A. (1964) Effect of paracetamol ( $\mathrm{N}$-acetyl-p-aminophenol) on gastrointestinal bleeding. Gut, 5, 463.

Goulston, K., Skyring, A.P. \& McGovern, V.J. (1965) Ulcerative jejunitis associated with malabsorption. Australasian Annals of Medicine, 14, 57.

GraceY, M. \& ANDERSON, C.M. (1969) Cystic fibrosis of the pancreas in adolescence and adulthood. Australasian Annals of Medicine, 18, 91.

Hall, G.J.L. \& Davis, A.E. (1969) Inhibition of iron absorption by magnesium trisilicate. Medical Journal of Australia, ii, 95.

Hughes, E.S.R. (1961a) The course of proctitis and mild proctocolitis. Australian and New Zealand Journal of Surgery, 31, 137.

HUGHES, E.S.R. (1961b) Acute ulcerative colitis. Diseases of the Colon and Rectum, 4, 3.

Hughes, E.S.R. (1969) Ulcerative colitis developing in Childhood. Medical Journal of Australia, i, 443.

Hughes, E.S.R. (1967) Ileorectal anastomosis for ulcerative colitis. Disease of the Colon and Rectum, 10, 35.

Joske, R.A., FINCKH, E.G. \& WoOD, I.J. (1955) Gastric biopsy, a study of 1000 consecutive successful biopsies. Quarterly Journal of Medicine, 24, 269.

Joske, R.A. (1955a) Pancreatitis following pregnancy. British Medical Journal, 1, 125.

JosKe, R.A. (1955b) Aetiological factors in the pancreatitis syndrome. British Medical Journal, 2, 1477.

JosKE, R.A. (1955c) The association of viral hepatitis and pancreatitis. The Royal Melbourne Hospital Clinical Reports, 25, 1.
Joske, R.A. (1960) Primary carcinoma of the jejunum with atrophic jejunitis and intestinal malabsorption. Gastroenterologv, 38, 810.

Joske, R.A. (1969) The diagnosis of Pancreatic disease. An evaluation of some laboratory methods. Medical Journal of Australia, i, 211.

Joske, R.A. \& BlACKWell, J.B. (1959) Alimentary histology in the malabsorption syndrome following partial gastrectomy. Lancet, ii, 379.

JoSKe, R.A., FINCKH, E.S. \& WoOD, I.J. (1955) Gastric biopsy: the study of 1000 consecutive successful biopsies. Quarterly Journal of Medicine, 24, 269.

Joske, R.A. \& KING, W.E. (1955) The 'L.E. Cell' phenomenon in active chronic viral hepatitis. Lancet, ii, 477.

Joske, R.A., Leak, P.J., Papadimatriou, J.M., Stanley, N.F. \& WALTERS, M.N-I. (1966) Murine infection with reovirus. British Journal of Experimental Pathology, 47, 337.

Joske, R.A., Shammaia, M.H. \& Drummery, G.D. (1958) Intestinal malabsorption following temporary occlusion of the superior mesenteric artery. American Journal of Medicine, 25, 449.

Kimber, C., Deller, D.J., Ibbotson, R.N. \& Lander, H. (1965a) The mechanism of anaemia in chronic liver disease. Quarterly Journal of Medicine, 34, 33.

Kimber, C.L., Deller, D.J. \& LANDer, H. (1965b) Megaloblastic and transitional megaloblastic anaemia associated with chronic liver disease. A study of nine cases. American Journal of Medicine, 38, 767.

KING, W.E. (1946) The sequelae of hepatitis. Proceedings of the Royal Australasian College of Physicians, 1, 8.

KING, M.J. \& Joske, R.A. (1960) Acute enteritis with temporary intestinal malabsorption. British Medical Journal, $1,1324$.

Lloyd, H.M., Powell, L.W. \& Thomas, M.J. (1964) Ideopathic haemochromatosis in menstruating women. Lancet, ii, 555.

MA, M.H. \& BlackbuRn, C.R.B. (1966) Virus like particles in a human primary hepatocarcinoma. Nature (London), 212, 854.

MA, M.H., McLeod, J.G. \& Blackburn, C.R.B. (1969) Long term treatment of portal systemic encephalopathy with lactulose. Australasian Annals of Medicine, 18, 117.

Ma, M.H., BLACKBURN, C.R.B., MCGovern, V.J., Burchett, P. \& ARTer, W.J. (1968) Liver disease in the territory of Papua and New Guinea. II. Histological observations on liver tissue on patients in hospital. Tropical and Geographical Medicine, 20, 307.

McCutcheon, A.D. (1968) A fresh approach to the pathogenesis of pancreatitis. Gut, 9, 296.

McCutcheon, A.D. \& RACE, D. (1962) Experimental pancreatitis: a possible aetiology of postoperative pancreatitis. Annals of Surgery, 155, 523.

MCGovern, V.J. \& ARCHER, G.T. (1957) The pathogenesis of ulcerative colitis. Australasian Annals of Medicine, 6, 68.

McGovern, V.J. \& Goulston, S.J.M. (1965) Ischaemic enterocolitis. Gut, 6, 213.

McGovern, V.J. \& Goulston, S.J.M. (1968) Crohn's disease of the colon. Gut, 9, 164.

McGuinness, A.E. \& Joasoo, A. (1969) Recovery from aplastic anaemia associated with infectious hepatitis. Medical Journal of Australia, 1, 1090.

MACKAY, I.R. (1961) The problem of persisting destructive disease of the liver. Gastroenterology, 40, 617.

MACKAY, I.R. \& GAJDUSEK, D.C. (1958) An auto-immune reaction against human tissue antigens in certain acute and chronic diseases. II. Clinical correlations. Archives of Internal Medicine, 101, 30. 
MACKay, I.R., WeIDEN, S. \& UngaR, B. (1964) Treatment of active chronic hepatitis and lupoid hepatitis with 6-Mercaptopurine and azothioprine. Lancet, i, 899.

MACKAY, I.R. \& WoOD, I.J. (1961) Autoimmunity in liver disease, Chap. 3, Progress in Liver Diseases, Vol. 1. (Ed. by H. Popper \& F. Schaffner).

MACKAY, I.R. \& Wood, I.J. (1962) Lupoid hepatitis. A comparison of 22 cases with other types of chronic liver disease. Quarterly Journal of Medicine, 31, 485.

MACKAY, I.R. \& WoOD, I.J. (1963) The course and treatment of lupoid hepatitis. Gastroenterology, 45, 4.

Middeten, W.R.J. (1967) Small bowel tumours. Australasian Annals of Medicine, 16, 155.

MiLton, G.W. (1962) The behaviour of gastric epithelium under various circumstances. Annals of the Royal College of Surgeons of England, 30, 351.

Milton, G.W. \& FincKH, E.S. (1960) Dedifferentiation and loss of acid secretion in exteriorized gastric mucosa. Gastroenterology, 39, 312.

Milton, G.W., Maxwell, G.A. \& Finckh, E.S. (1960) Changes in gastric acidity and epithelial regeneration following excision of gastric mucosa in the dog. British Journal of Surgery, 47, 562.

Mistilis, S.P. (1965) Pericholangitis and ulcerative colitis. 1. Pathology, etiology and pathogenesis. Annals of Internal Medicine, 63, 1.

MistiLis, S.P. (1968) Natural history of active chronic hepatitis. II. Pathology, pathogenesis and clinicopathological correlation. Australian Annals of Medicine, 17, 277.

Mistilis, S.P. \& FARRer, P.A. (1968) The absorption of biliary and non-biliary radiocopper in the rat. Scandinavian Journal of Gastroenterology, 3, 586, 1968.

Mistilis, S.P. \& Goulston, S.J.M. (1965) 'Liver disease in Ulcerative Colitis' in Recent Advances in Gastroenterology. Churchill, London.

Mistilis, S.P. \& Mearrick, P.T. (1969) The absorption of ionic, biliary and plasma radiocopper in neonatal rats. Scandinavian Journal of Gastroenterology (In press).

Mistilis, S.P., Skyring, A.P. \& Blackburn, C.R.B. (1968) Natural history of active chronic hepatitis. 1. Clinical features, course, diagonostic criteria, morbidity, mortality and survival. Australasian Annals of Medicine, 17, 214.

Mistilis, S.P., Skyring, A.P. \& Goulston, S.J.M. (1965a) Pericholangitis and ulcerative colitis. II. Clinical aspects. Annals of Internal Medicine, 63, 17.

Mistilis, S.P., Skyring, A.P. \& Goulston, S.J.M. (1965b) Effect of long term tetracycline therapy, steroid therapy and colectomy in pericholangitis associated with ulcerative colitis. Australasian Annals of Medicine, 14, 286.

Mistilis, S.P., Skyring, A.P. \& Stephen, D. (1965) Intestinal lymphangiectasia: Mechanism of enteric loss of plasma protein and fat. Lancet, i, 77.

Murrell, T.G.C. (1967) Pig-Bel. Epidemic and sporadic necrotizing enteritis in the highlands of New Guinea. Australasian Annals of Medicine, 16, 4.

MyHill, J. \& Piper, D.W. (1964) Antacid therapy of peptic ulcer. Mathematical definition of an adequate dose. Gut, $5,581$.

O'Brien, E.N., Goble, A.J. \& Mackay, I.R. (1958) Plasma transaminase activity as an index of the effectiveness of cortisone in chronic hepatitis. Lancet, i, 1245.

Perkins, K.W., McInnes, I.W.S., Blackburn, C.R.B. \& BEAL, R.W. (1965) Ideopathic haemochromatosis in Children. American Journal of Medicine, 39, 118.

PIPER, D.W. (1967) Antacid and anticholinergic drug therapy of peptic ulcer. Gastroenterology, 52, 1009.

PIPER, D.W. (1968) Organic constituents in human gastric juice with special reference to the secretory abnormalities in gastric carcinoma. Progress in Gastroenterology, Vol. 1, Chapter 8, p. 157. (Ed. G. B. Jerzy Glass.) Grune \& Stratton, New York.
Piper, D.W. \& Fenton, B.H. (1964) Antacid therapy of peptic ulcer. 2. An evaluation of antacids in vitro. Gut, $5,585$.

Piper, D.W., Macoun, M.L., Broderick, F.L., Fenton B.H. \& BuILDER, J.E. (1963) The diagnosis of gastric carcinoma by the estimation of enzyme activity in gastric juice. Gastroenterology, 45, 614.

Pirola, R.C. \& Davis, A.E. (1968) Effects of ethyl alcohol on sphincteric resistance at choledocho-duodenal junction in man. Gut, 9, 557.

Powell, L.W. (1965) Iron storage in relatives of patients with haemochromatosis and in relatives of patients with alcoholic cirrhosis and haemosiderosis. Quarterly Journal of Medicine, 34, 427.

Powell, L.W. (1966) Normal human iron storage and its relation to ethanol consumption. Australasian Annals of Medicine, 15, 110.

Preshaw, R.M., Cookea, R. \& Grossman, M.I. (1965) Stimulation of pancreatic secretion by a humoral agent from the pyloric gland area of the stomach. Gastroenterology, 49, 617.

Ralston, Mary, Wood, I.J. \& Hughes, A. (1960) Small bowel biopsy with the suction biopsy tube. Australasian Annals of Medicine, 9, 103.

Rankin, J.G., Skyring, A.P. \& Goulston, S.J.M. (1966) Liver in ulcerative colitis. Obstructive jaundice due to bile duct carcinoma. Gut, 7, 433.

Rankin, J.G., Boden, R.W., Goulston, S.J.M. \& Morrow, A.W. (1959) The liver in ulcerative colitis. Treatment of pericholangitis with tetracycline. Lancet, ii, 1110.

RANKIN, J.G., Goulston, S.J.M., BODEN, R.W. \& Morrow, A.W. (1960) Fulminant ulcerative colitis. Quarterly Journal of Medicine, 29, 375.

RudZKI, Z. \& DelleR, D.J. (1969) Isolation and partial characterization of the iron binding component in human gastric juice. (Abstract.) Australasian Annals of Medicine, $18,32$.

Russell, I.S. \& Hughes, E.S.R. (1961) Carcinoma of the colon complicating ulcerative colitis. Australian and New Zealand Journal of Surgery, 30, 306.

SAINT, E.G. (1954) Acute pancreatitis. Medical Journal of Australia, ii, 536.

SAINT, E.G., KING, W.E., Joske, R.A. \& FINCKH, E.S. (1953) The course of infectious hepatitis with special reference to prognosis and the chronic stage. Australasian Annals of Medicine, 2, 113.

SaINT, E.G. \& WeIDeN, S. (1953) Studies on pancreatitis. British Medical Journal, 2, 1335.

Scheuer, P.J., Thorpe, M.E.C. \& MARRiott, P. (1967) A method for the demonstration of copper under the electron microscope. Journal of Histochemistry and Cytochemistry, $15,300$.

SkYRING, A.P. \& RoberTs, R. (1965) Childhood ulcerative colitis: an epidemiological study in N.S.W. Medical Journal of Australia, i, 955.

Skyring, A., Singer, A. \& Tornya, P. (1965) Treatment of acute pancreatitis with Trasylol. Report of a controlled therapeutic trial. British Medical Journal, 2, 627.

Stathers, G.M., Ma, M.H. \& BlackBURN, C.R.B. (1968) Extrahepatic portal hypertension: the clinical evaluation, investigation and results of treatment of 28 patients. Australasian Annals of Medicine, 17, 12.

ST. JoHN, D.J.B. \& MCDERmotT, F.T. (1969) The effect of aspirin upon gastrointestinal blood loss in pernicious anaemia. Abstract, Australasian Annals of Medicine, 18, 182.

ThORPE, M.E.C., Scheuer, P.J. \& SHERlock, S. (1967) Primary sclerosing cholangitis, the biliary tree, and ulcerative colitis. Gut, 8, 435 .

THORPE, M.E.C. \& SHOREY, C.D. (1966a) Ultrastructural alterations in human liver disease. Australasian Annals of Medicine, 15, 4. 
ThORPE, M.E.C. \& Shorey, C.D. (1966b) Long-term alcohol administration: its effect on the ultrastructure and lipid content of the rat liver cell. American Journal of Pathology, 48, 557.

TODD, A.P., Thorpe, M.E.C. \& Rosenoer, V.M. (1967) Tissue copper determinations by neutron activation analysis. Journal of Clinical Pathology, 20, 276.

WALKer-Smith, J.A., SkYRING, A.P. \& Mistilis, S.P. (1966) Use of $\mathrm{Cr}^{51} \mathrm{Cl}_{3}$ in diagnosis of protein losing enteropathy. Gut, 8, 166.

W ANGEL, A.G. \& Deller, D.J. (1965a) Intestinal motility in man. II. The behaviour of the small intestine following partial gastrectomy with particular reference to the dumping syndrome. Gastroenterology, 48, 58.

WANGel, A.G. \& Deller, D.J. (1965b) Intestinal motility in man III. Mechanisms of constipation and diarrhoea with particular reference to the irritable colon syndrome. Gastroenterology, 48, 69.
Whituingham, S., Irwin, J., Mackay, I.R. \& Smalley, M. (1966) Smooth muscle auto-antibody in 'autoimmune' hepatitis. Gastroenterology, 51, 499.

WhitTinghaM, S., MACKAY, I.R. \& IRWIN, J. (1966) Autoimmune hepatitis. Immunofluorescence reactions with cytoplasm of smooth muscle and renal glomerular cells. Lancet, i, 1333.

WoOd, I.J., Motteram, R. \& Hughes, A. (1949) Gastric biopsy: Report on 55 biopsies using a new flexible gastric biopsy tube. Lancet, i, 18.

Wood, I.J., Doig, R.K., Motteram, R., Weiden, S. \& Moore, A. (1949) The relationship between the secretions of the gastric mucosa and its morphology as shown by biopsy specimens. Gastroenterology, 12, 949.

Wood, I.J., Ralston, M., Ungar, B. \& Cowling, D.C. (1964) Vitamin $B_{12}$ deficiency in chronic gastritis. Gut, 5, 27.

WoOD, I.J. \& TAFT, L.I. (1958) Diffuse Lesions of the Stomach. Edward Arnold, London. 